\title{
BODY CONDITION SCORE OF EGYPTIAN EWES: DOES IT AFFECT REPRODUCTIVE AND PRODUCTIVE PERFORMANCES?
}

\section{Ibrahim Abdel-Mageed}

Department of Animal Production, Faculty of Agriculture, University of Cairo, 12613, Giza, Egypt

\section{SUMMARY}

One-hundred and twenty six ewes of the three main Egyptian sheep breeds (Rahmani, Barki and Ossimi) were used to investigate the effect of body condition score (BCS) of ewes at mating on their reproductive and productive performances. Ewes were classified to four classes according to their body conditions $(\leq 2,2.5,3$ and 3.5).

The experimental design was completely randomized with 12 groups arranged factorially ( $3 x \quad 4)$ with breed of ewes and BCS as main effects and the interaction was considered. Data of the reproductive traits were analyzed by chi square using CATMOD procedure. While data of the productive traits were analyzed using the GLM of SAS (2004). No interactions between breed of ewes and BCS were observed. Therefore, means of main effects for all traits were presented.

Breed of ewes did not significantly affect the studied reproductive and productive traits. However BCS of ewes significantly affected all the studied reproductive and productive traits except lambs born / ewe lambing, lambs weaned / ewe lambing and lamb survival at weaning. There were no significant differences between ewes having $B C S$ of 3 and 3.5 in all reproductive and productive studied traits. Therefore, to optimize profitability of sheep flocks, it is recommended to control the body condition of ewes at mating around the score 3.

\section{Keyword: Ewes, body condition, reproduction, lamb crop}

\section{INTRODUCTION}

For increasing lamb crop and enhancing profitability of sheep enterprises, it is too important to produce viable newborn lambs with subsequent heavy weaning weights. This aim can be achieved by raising ewes of good body condition. Therefore, it is recommended to frequently quantifying body reserve changes of ewes.

There are about 5 million heads of sheep in Egypt (FAO, 2008). The main sheep breeds are Rahmani, Barki and Ossimi. Most holders of commercial sheep flocks in Egypt use weight to evaluate the status of ewes before mating, while very few use body condition score (BCS).

The most widely practiced estimator of fatness in live sheep 40 years ago (Russel et al., 1969) to near past (Caldeira et al., 2007a \&b; Malau-Aduli et al., 2007; AbdelMageed, 2009; Kenyon et al., 2010; and Wallace et al., 2010) has been BCS. Body weight, alone, is not a sufficient descriptor of the animal to correctly predict feed

Issued by The Egyptian Society of Animal Production 
intake (Tolkamp et al., 2006) or carcass fat content (Silva et al., 2005). Predictions were improved by taking BCS into account. In addition, BCS has been widely accepted as the most practical method for assessing changes in energy reserves in many species (Bewley and Schutz, 2008).

Subjective estimates of body condition are used widely by farmers and technicians, in many countries, for describing body condition in sheep, based on a five-point scale assessed by palpation of the lumbar region. This method assesses mainly subcutaneous fat cover with some indications of muscle thickness. A subjective BCS system can be useful in assessing the nutritional status of ewes (Atti and Ben Hammouda 2004 and Thompson and Cheeke, 2005) and to monitor the general metabolic status of ewes on a regular basis (Caldeira et al., 2007b). Therefore, BCS provides not only a reliable prediction of the reserves available to comply with the animal's need, but its way of changing can also offer a broad picture of the predominant orientation of metabolism.

In Egypt, very little information is available about BCS and its relationship to reproduction and lamb crop in ewes. Therefore, the aim of this study was to investigate the effect of BCS of ewes, at mating, of the three main Egyptian sheep breeds (Rahmani, Barki and Ossimi) on their reproductive and productive performances.

\section{MATERIAL AND METHODS}

The present study was carried out at the experimental farm of the Animal Production Department, Faculty of Agriculture, Cairo University, Giza, Egypt, during the period from May 2007 to February 2008.

\section{Animals and management:}

Three Egyptian sheep breeds (Rahmani [R], Barki [B] and Ossimi [O], table 1) were used to investigate the effect of body condition score (BCS) of ewes at mating on their reproductive and productive performances.

Table 1. Numbers of ewes in the three studied breeds and the four body condition score (BCS) classes

\begin{tabular}{ccccc}
\hline BCS & Rahmani & Barki & Ossimi & Total \\
\hline$\leq \mathbf{2}$ & 16 & 7 & 5 & $\mathbf{2 8}$ \\
$\mathbf{2 . 5}$ & 10 & 20 & 18 & $\mathbf{4 8}$ \\
$\mathbf{3}$ & 9 & 16 & 10 & $\mathbf{3 5}$ \\
$\mathbf{3 . 5}$ & 5 & 7 & 3 & $\mathbf{1 5}$ \\
Total & $\mathbf{4 0}$ & $\mathbf{5 0}$ & $\mathbf{3 6}$ & $\mathbf{1 2 6}$ \\
\hline
\end{tabular}

Two days before the onset of breeding season (May - June), ewes were weighed and body condition was scored. The BCS was measured by using the technique of Russel et al. (1969) which employs a 1 to 5 score scale, with an interval range of 0.5 point. The lowest score indicates an extremely emaciated sheep, and 5 represents excessive obesity. Body condition is assessed by handling over and around the backbone, on the loin area immediately behind the last rib and above the kidney, using the fingers along the top and sides of the backbone. 
Ewes were kept in semi-shaded pens, where drinking water was available all day. Egyptian clover (Trifolium alexandrinum), clover hay, concentrate mixture (13\% CP and $0.65 \mathrm{~kg}$ TDN) and wheat straw were used for ration formulation according to the season of the year. Feeding requirements of ewes were calculated according to NRC (1985).

\section{Estrus synchronization and mating:}

Ewes were estrus-synchronized with two intramuscular doses of Estrumate $\left(\mathrm{PGF}_{2 \alpha}\right.$, each of $1 \mathrm{ml}, 250 \mu \mathrm{g}$ Cloprostenol, Coopers Co., England) at 11- day interval. Simultaneously with the $2^{\text {nd }}$ dose of Estrumate, fertile rams of the same breed of ewes were introduced with a ratio of 1:10 for 45 days.

\section{Measured traits:}

Both reproductive and productive traits were measured. The reproductive traits are ovulation rate $(\mathrm{OR})$, ewes conceived per ewes joined (EC/EJ), ewes lambed per ewes joined (EL/EJ), lambs born per ewe joined (LB/EJ), lambs weaned per ewe joined $(\mathrm{LW} / \mathrm{EJ})$, lambs born per ewe lambing $(\mathrm{LB} / \mathrm{EL})$, lambs weaned per ewe lambing (LW/EL), ova wastage at lambing (OWL), ova wastage at weaning (OWW) and lamb survival at weaning (LSW). While the productive traits are kilograms born per ewe joined $(\mathrm{KgB} / \mathrm{EJ})$, kilograms weaned per ewe joined $(\mathrm{KgW} / \mathrm{EJ})$, kilograms born per ewe lambing (KgB/EL), kilograms weaned per ewe lambing $(\mathrm{KgW} / \mathrm{EL})$ and kilograms weaned per ewe weaning $(\mathrm{KgW} / \mathrm{EW})$.

Ovulation rate was measured by counting corpora lutea using ultrasonography at 7-10 days after mating. Ova wastage at lambing was calculated as the difference between ovulation rate and lambs born, in relation to ovulation rate. Ova wastage at weaning was calculated as the difference between ovulation rate and lambs weaned, in relation to ovulation rate. Lamb survival at weaning was calculated as the difference between lambs born and lambs weaned, in relation to lambs born.

\section{Statistical analyses:}

The experimental design was completely randomized with 12 groups arranged factorially $(3 * 4)$ with breed of ewes (Rahmani, Barki and Ossimi) and BCS $(\leq 2$, 2.5, 3 and 3.5) as main effects and the interaction was considered. Data of reproductive traits were not normally distributed as indicated by UNIVARIATE procedure and the variances were not homogeneous as indicated by HOVTEST option (SAS, 2004). Therefore, reproductive traits were analyzed using chi square CATMOD procedure (SAS, 2004). Means were obtained and contrasts were carried out to detect differences among effects for reproductive traits. Data of the productive traits were analyzed using the GLM procedure (SAS, 2004). Least Squares Means (LSM) were obtained for the productive traits. Duncan's multiple range test was used to detect differences among means for productive traits. The significance level was set at 5\%. 


\section{RESULTS AND DISCUSSION}

To the best of our knowledge, this is the first study to report the impact of the BCS of ewes of Egyptian local sheep breeds, at mating, on their reproductive and productive performances. In Egypt, only one report (Abdel-Mageed, 2009) was previously published about the relationship between BCS of local Ossimi ewes and some fertility and prolificacy traits.

No interactions between breed of ewes and their BCS were observed for all traits. Therefore, the results highlighted the impact of main effects on the reproductive and productive performances of ewes.

\section{Reproductive traits:}

Breed of ewes did not significantly affect the studied reproductive traits. While BCS of ewes were significantly affected all the studied reproductive traits except LB/EL, LW/EL and LSW (Figs. 1 and 2).
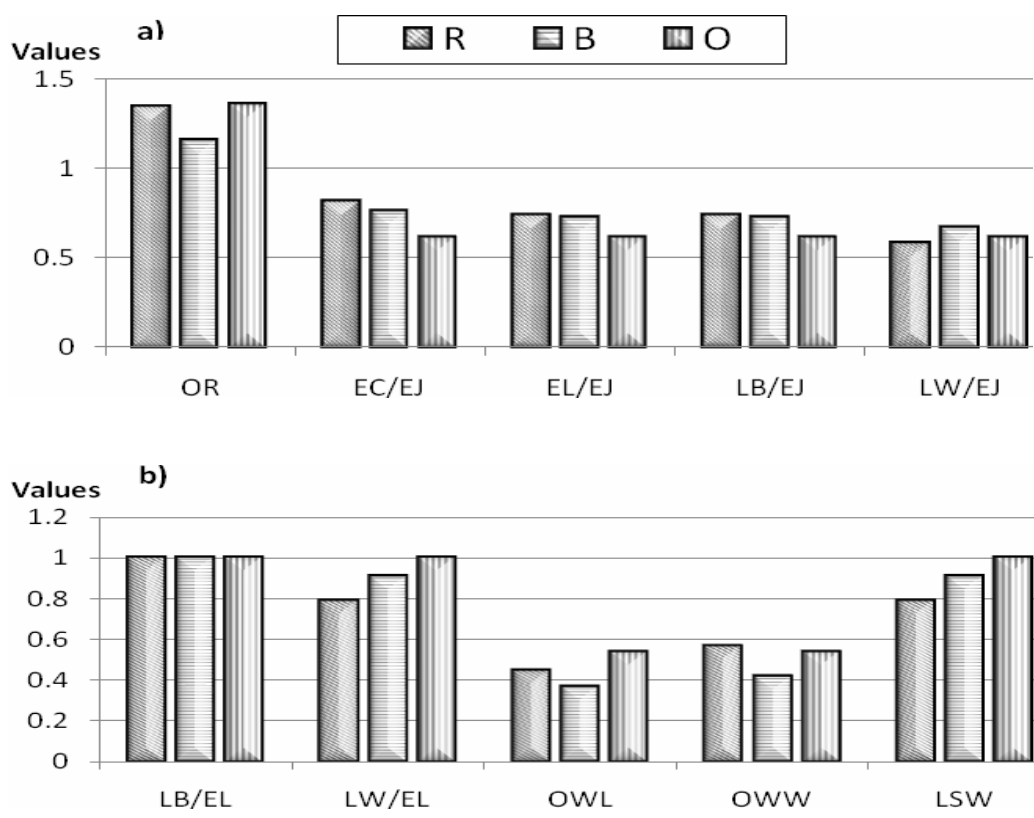

Figure 1. Effect of breed of ewes [Rahmani (R), Barki (B) and Ossimi (O)] on their reproductive traits: a) ovulation rate $(\mathrm{OR})$, ewes conceived per ewes joined (EC/EJ), ewes lambed per ewes joined(EL/EJ), lambs born per ewe joined(LB/EJ) and lambs weaned per ewe joined (LW/EJ); b) lambs born per ewe lambing (LB/EL), lambs weaned per ewe lambing (LW/EL), Ova wastage at lambing (OWL), ova wastage at weaning (OWW) and lamb survival at weaning (LSW). 
The non-significant differences among ewes of the three studied breeds for reproductive and productive traits were previously confirmed in many reports (Gabr et al., 1989; Aboul-Naga et al., 1992 and Afifi et al. 1996).

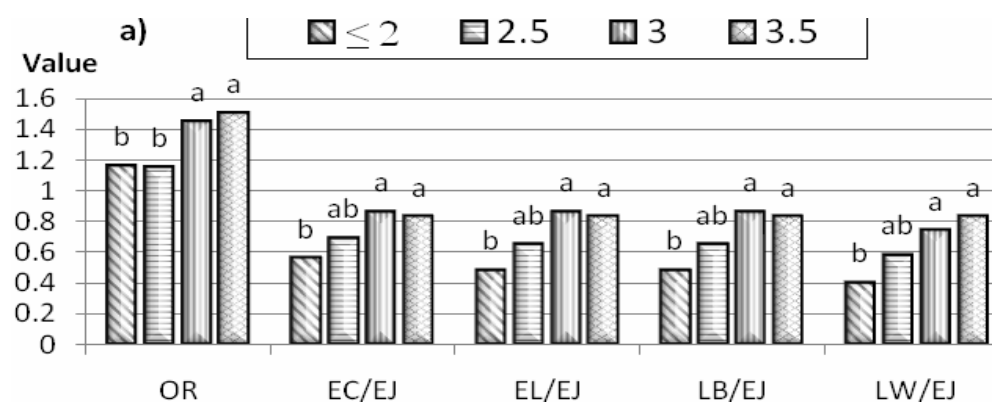

b)

\section{Value}

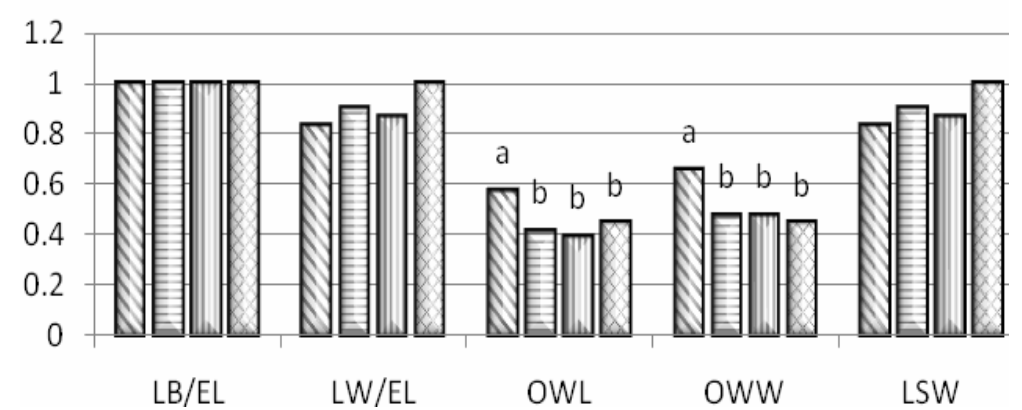

Figure 2. Effect of body condition score(BCS) of ewes (BCS $\leq 2,2.5,3$ and 3.5) on their reproductive traits: a) ovulation rate (OR), ewes conceived per ewes joined (EC/EJ), ewes lambed per ewes joined(EL/EJ), lambs born per ewe joined(LB/EJ) and lambs weaned per ewe joined (LW/EJ); b) lambs born per ewe lambing (LB/EL), lambs weaned per ewe lambing (LW/EL), Ova wastage at lambing (OWL), ova wastage at weaning $(\mathrm{OWW})$ and lamb survival at weaning (LSW).

Columns with different letters differ significantly from each other $(\mathrm{P}<0.05)$.

Ewes that had higher BCS ( 3 and 3.5) had significantly higher $(\mathrm{P}<0.01)$ OR compared to the lower BCS $(\leq 2$ and 2.5). The significant effects of BCS on OR of ewes, in the present study, were previously confirmed in many reports. Many researchers found positive relationships between BCS and OR in small ruminants, either in sheep (Gunn et al., 1969 \& 1972; Gunn and Doney, 1975; Rhind et al., 1986; Boland et al., 1993; and Rondon et al., 1996) or in goat (Meza-Herrera et al., 2008). Rhind and McNeilly (1998) concluded that, high levels of ewe BCS results in 
the development of a greater number of large, oestrogenic follicles compared with ewes in low condition. These differences are then reflected in the ovulation rates of these ewes. On the other hand, Rhind et al. (1990) and Pearse et al. (1994) stated that OR was not significantly affected by the BCS of ewes.

Ewes with BCS of 3 and 3.5 had significantly higher $(\mathrm{P}<0.01) \mathrm{EC} / \mathrm{EJ}, \mathrm{EL} / \mathrm{EJ}$, $\mathrm{LB} / \mathrm{EJ}$ and LW/EJ compared to those having BCS $\leq 2$ (Fig. 2). Ewes having BCS of $\leq 2$ had significantly higher $(\mathrm{P}<0.05) \mathrm{OWL}$ and $\mathrm{OWW}$ compared to the other ewes with higher BCS.

Abdel-Mageed (2009) reported high EC/EJ and EL/EJ scores in Ossimi ewes with BCS of 3. The results of the present study are similar to those of Abdelmageed (2009). Actually, many reports pointed out the importance of moderate BCS of ewes for increasing pregnancy outcomes. Rhind et al. (1990) observed significantly higher $(\mathrm{P}<0.05)$ pregnancy rate for moderate BCS ewes $(2.5-2.75)$ than the higher BCS ewes $(\geq 3.5)$. Similarly, Kenyon et al. (2010) concluded that, ewe lambs with a condition score of 2.5 or greater had significantly higher $(\mathrm{P}<0.05)$ pregnancy rates than those with a condition score of 2.0 and 1.5. Malau-Aduli et al. (2007) concluded that ewes conceived had slightly greater BCS (2.85) than barren ewes (2.77). McEwan et al. (2001) observed significantly higher $(\mathrm{P}<0.05)$ estimate for EL/EJ in moderate $\mathrm{BC}$ ewes compared to fatter ones.

All ewes that were used in the present study gave birth to single lambs. Egyptian sheep are considered as non prolific breeds (Mokhtar et al., 1991 and Aboul-Naga et al., 1992). This is particularly true for summer mating season (May - July) that was applied in the present study. However, ewes with BCS of 3 and 3.5, in the present study, had the highest LB/EJ and LW/EJ. Many previous reports confirmed these results. Significantly higher $(\mathrm{P}<0.05) \mathrm{LB} / \mathrm{EJ}$ scores of Ossimi ewes were observed for BCS of 3 and 3.5 compared to higher (4) or lower $(1.5-2)$ BCS (Abdel-Mageed, 2009). Rhind et al. (1986) observed higher number of embryos per ewe mated (1.42) at 38 days of conception in the higher BCS ewes (3.35) compared to the moderate ones (1.16 for 2.74BCS). However, after selection for backfat depth for 14 years in Scottish Blackface sheep, the fat line ewes had lower LW/EJ (1.22) compared to the control line (1.33) or the lean line (1.26) (McEwan et al., 2001).

The relatively higher survival rate of lambs from ewes with BCS of 3.5, in the present study, may be due to the sufficiency of their body reserves for milk production as previously suggested by Henderson (1990). Accordingly, Thompson and Cheeky (2005) reported that, ewes which are expected to give birth to or that are nursing twins should have 0.5 higher condition score (3.5) at the respective stages of production.

All conceived ewes with BCS of 3 and 3.5 gave birth compared to 86 and $94 \%$ of those who had $\mathrm{BCS} \leq 2$ and 2.5 , respectively. These results were previously confirmed by Abdel-Mageed (2009) in the Egyptian Ossimi sheep. He reported high estimates $(10-17 \%)$ of abortion for ewes that had the lowest and the highest BCS (1.5 and 4) compared to moderate BCS (2.5 and 3) ones $(0-2 \%)$. In addition, ewes with low BCS were associated with higher prenatal loss (West et al., 1989). Lake et al. (2006) concluded that, reduction in body fat was associated with impairing reproductive efficiency in farm animals. Also, Bewley and Schutz (2008) stated that, reduction in BCS throughout the lactation period can have negative impact on milk yield, herd health, reproductive performance and animal well-being. Henderson 
(1990) stated that, sufficient body reserves are required for utilization during pregnancy and lactation.

\section{Productive traits:}

All the studied productive traits were not significantly affected by the breed of ewes (Fig. 3). However, all the studied productive traits were significantly affected by the BCS of ewes (Fig. 4).

The traits of $\mathrm{KgB} / \mathrm{EJ}, \mathrm{KgW} / \mathrm{EJ}, \mathrm{KgB} / \mathrm{EL}, \mathrm{KgW} / \mathrm{EL}$ and $\mathrm{KgW} / \mathrm{EW}$ increased significantly $(\mathrm{P}<0.01)$ and gradually with increasing the BCS of ewes. Similarly, the productive traits increased gradually with increasing the BCS of ewes within the three studied breeds. However, no significant differences were found between ewes with BCS of 3 and 3.5 for the five traits.

The non-significant differences between body condition score 3 and 3.5, in the present study, for $\mathrm{KgB} / \mathrm{EJ}$ and $\mathrm{KgW} / \mathrm{EJ}$ is in accordance with the findings of AlSabbagh et al. (1995) and Abdel-Mageed (2009). Abdel-Mageed (2009) reported significantly higher $(\mathrm{P}<0.05) \mathrm{KgB} / \mathrm{EJ}$ for Ossimi ewes with $\mathrm{BCS}$ of 3 and 3.5 compared to higher (4) or lower $(1.5-2)$ BCS. Wallace et al. (2010) concluded that, maternal body mass index (good, 2.6 or poor, 2.1 adiposity score) at conception had a profound influence on pregnancy outcome in adolescent sheep. Placental and lamb birth weights were higher in good adiposity ewe-lambs than the poor ones. The present result conforms with that of Wallace et al. (2010). Therefore, raising BCS ewes can be a key role in maximization of animal potential as previously stated by Bewley and Schutz (2008).

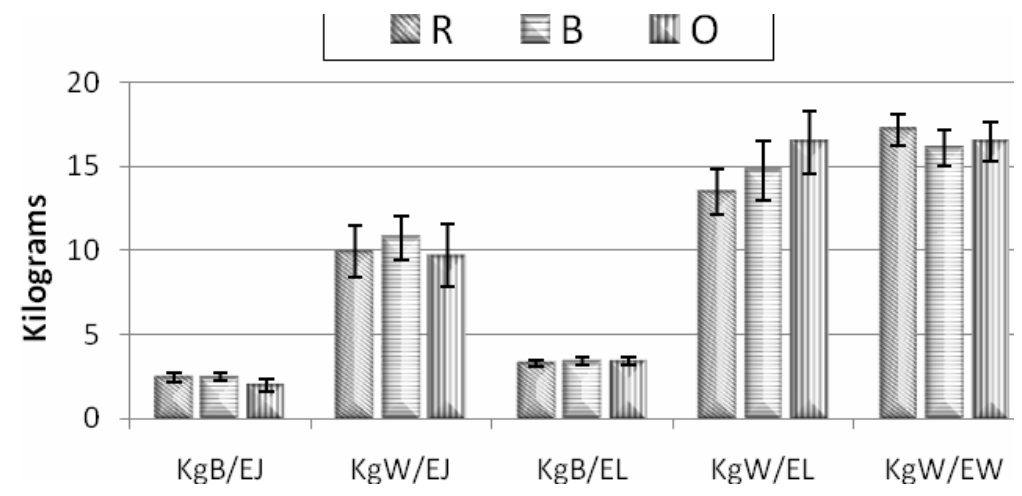

Figure 3. Effect of breed of ewes [Rahmani (R), Barki (B) and Ossimi (O)] on their productive traits (LSM and SE bars): Kilograms born per ewe joined (KgB/EJ), kilograms weaned per ewe joined (KgW/EJ), kilograms born per ewe lambing $(\mathrm{KgB} / \mathrm{EL})$, kilograms weaned per ewe lambing (KgW/EL) and kilograms weaned per ewe weaning $(\mathrm{KgW} / \mathrm{EW})$. 


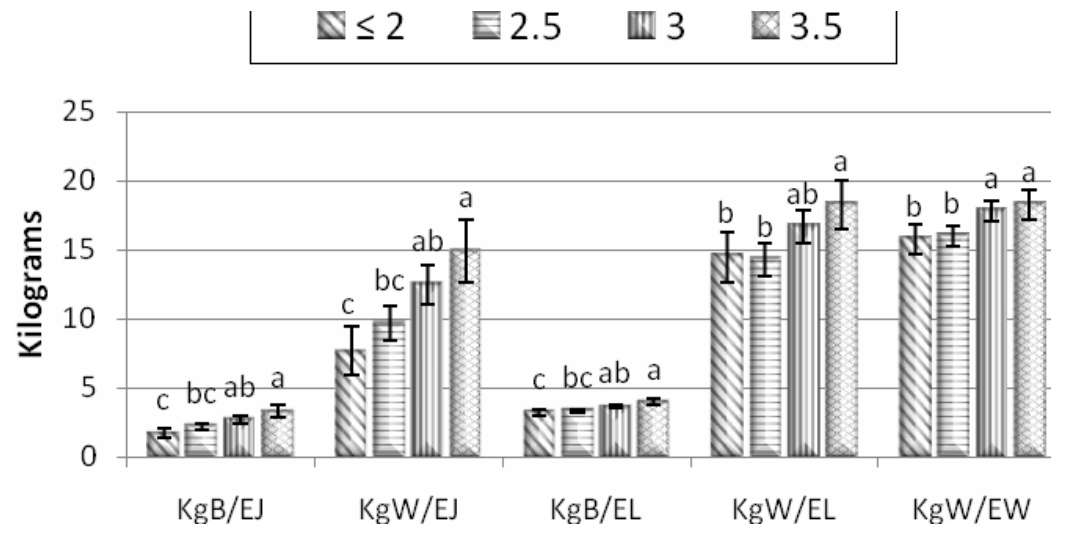

Figure 4. Effect of body condition score(BCS) of ewes (BCS $\leq 2,2.5,3$ and 3.5) on their productive traits (LSM and SE bars): Kilograms born per ewe joined $(\mathrm{KgB} / \mathrm{EJ})$, kilograms weaned per ewe joined (KgW/EJ), kilograms born per ewe lambing $(\mathrm{KgB} / \mathrm{EL})$, kilograms weaned per ewe lambing $(\mathrm{KgW} / \mathrm{EL})$ and kilograms weaned per ewe weaning $(\mathrm{KgW} / \mathrm{EW})$.

Columns with different letters differ significantly from each other $(P<0.05)$.

Thomas et al. (1988) observed significantly higher $(\mathrm{P}<0.05)$ birth weight for lambs produced from 3.5 BCS versus 2.5 BCS ewes. This is online with the results of the present study. On the contrary, Osgerby et al. (2003) concluded that the lean Dorset ewes $(\mathrm{BCS}=2)$ had slightly higher $(\mathrm{P}>0.05)$ fetus weights at 65 days of gestation compared to the fatter ewes (BCS = 3.5). However, Al-Sabbagh et al. (1995) stated that, the range of 2.5 to $3.5 \mathrm{BCS}$ ewes at lambing was not an important factor affecting colostral IgG concentration, total weight of lambs born, lamb mortality from birth to weaning and total weigh of lambs weaned.

Additional research is needed on a large-scale, particularly for commercial sheep flocks, to better quantify the real impact of nonoptimal BCS of Egyptian ewe breeds on their reproductive and productive performances. Using ultrasonography is more objective than traditional BCS, therefore, additional research is also needed to quantify the backfat of Egyptian local sheep breeds and relate it with reproductive and productive performances of ewes. Measuring backfat thickness using ultrasound is preferred over BCS because of its precision, speed and ease of use as previously proposed by Schruder and Staufenbiel (2006).

\section{CONCLUSION}

There were no significant differences observed between ewes having BCS of 3 or 3.5 in all reproductive and productive studied traits. Therefore, to raise profitability of sheep flocks it is recommended to maintain ewes that have BCS of 3 to reduce expenses, time and effort. However, it is not recommended to keep ewes having BCS less than 2 in the flock. 


\section{REFERENCES}

Abdel-Mageed I., 2009. Body condition scoring of local Ossimi ewes at mating and its impact on fertility and prolificacy. Egyptian J. Sheep \& Goat Sci. 4 (1), 37-44.

Aboul-Naga A.M., M.B. Aboul-Ela and F. Hassan, 1992. Manipulation of reproductive activity in subtropical sheep. Small Rumin. Res. 7, 151-160.

Afifi E.A., A.I. El-Sayed and M.R. El-Mahdy, 1996. Some ewe reproductive and lamb growth traits in Rahmani, Ossimi sheep and their crosses. Annals of Agric. Sci. Moshtohor 34 (1), 139-156.

Al-Sabbagh T.A., L.V. Swanson and J.M. Thompson, 1995. The effect of ewe body condition at lambing on colostral immunoglobulin $\mathrm{G}$ concentration and lamb performance. J. Anim. Sci. 73, 2860-2864.

Atti N. and M. Ben Hammouda, , 2004. Relationships among carcass composition and tail measurements in fat-tailed Barbarine sheep. Small Rumin. Res. 53, 151155.

Bewley J.M. and M.M. Schutz, 2008. Review: An interdisciplinary review of body condition scoring of dairy cattle. The professional Animal Scientist 24, 507-529.

Boland M.P., J.V. O'Doherty, and T.F. Grosby, 1993. Superovulation in sheep influenced by FSH and body condition. Proceeding of the $9^{\text {th }}$ meeting Uropean Embryo Transfer Association (Lyon), p. 158.

Caldeira R.M., A.T. Belo, C.C. Santos, M.I. Vazques and A.V. Portugal, 2007a. The effect of body condition score on blood metabolites and hormonal profiles in ewes. Small Rumin. Res. 68, 233-241.

Caldeira R.M., A.T. Belo, C.C. Santos, M.I. Vazques and A.V. Portugal, 2007b. The effect of long-term feed restriction and over-nutrition on body condition score, blood metabolites and hormonal profiles in ewes. Small Rumin. Res. 68, 242-255.

FAO, 2008. FAO Statistical Year Book. www.FAO.org.

Gabr M.G., A.M. Aboul-Naga, M.B. Aboul-Ela and S.M. El-Nakhla, 1989. Seasonal variation in ovulation rate, litter size and ova wastage in local Rahmani and Ossimi ewes. Third Egyptian-British Conference on Animal, Fish and Poultry production.

Gunn R.G. and J.M. Doney, 1975. The interaction of nutrition and body condition at mating on ovulation rate and early embryo mortality in Scottish Blackface ewes. J. Agric. Sci. Camb. 85, 465-470.

Gunn R.G., J.M. Doney and A.J.F. Russel, 1969. Fertility in Scottish Blackface ewes as influenced by nutrition and body condition at mating. J. Agric. Sci. Camb. 73, 289-294.

Gunn R.G., J.M. Doney and A.J.F. Russel, 1972. Embryo mortality in Scottish Blackface ewes as influenced by body condition at mating and by post-mating nutrition. J. Agric. Sci. Camb. 79, 19-25.

Henderson D.C., 1990. "The Veterinary Book for Sheep Farmers". Farming Press Books, Ipswich.

Kenyon P.R., S.T. Morris and D.M. West, 2010. Proportion of rams and the condition of ewe lambs at joining influences their breeding performance. Anim., Prod. Sci. 50 (6), 454-459.

Lake S.L., E.J. Scholljegerdes, V. Nayigihugu, C.M. Murrieta, R.L. Atkinson, D.C. Rule, T.J. Robinson and B.W. Hess, 2006. Effect of body condition score at 
parturition and postpartum supplemental fat on adipose tissue lipogenic activity of lactating beef cows. J. Anim. Sci. 84, 397-404.

Malau-Aduli A.E.O., G.H. Bond and M. Dunbabin, 2007. Influence of body weight and body condition score at breeding on conception and prolificacy of Merino and Composite Coopworth , East Friesian, Romney and Texel sheep in Tasmania, Australia. J. Anim. Sci. 85, suppl. 1/J., 663 (abstr.).

McEwan J.C., C.A. Morris, P.F. Fennessy, G.J. Greer, W.E. Bainand and S.M. Hickey, 2001. Selection for high or low backfat depth in Coopworth sheep: breeding-ewe traits. Anim. Sci. 73, $241-252$.

Meza-Herrera C.A., D.M. Hallford, J.A. Ortiz, R.A. Cuevas, J.M. Sanchez, H. Salinas, M. Mellado and A. Gonzalez-Bulnes, 2008. Body condition and protein supplementation positively affect periovulatory ovarian activity by non LHmediated pathways in goat. Anim. Reprod. Sci. 106, 412-420.

Mokhtar M.M., H.T. Abdel Bary, A.A. Younis, M.S. Mabrouk and H. Abdel Aziz, 1991. Comparative study of two systems of production in Barki sheep. Egypt. J. Anim. Prod. 28 (1), 21-30.

NRC (1985). Nutrient Requirements of Sheep, $6^{\text {th }}$ Edition. NRC, Washington, DC., USA.

Osgerby J.C., T.S. Gadd and D.C. Wathes, 2003. Effect of maternal body condition on placental and fetal growth and the insulin-like growth factor axis in Dorset ewes. Reprod. 125, 717-731.

Pearse B.H.G., N.P. McMeniman and I.A. Gardner, 1994. Influence of body condition on ovulatory response to lupin (Lupinus angustifolius) supplementation of sheep. Small Rumin. Res. 13 (1), 27-32.

Rhind S.M. and A.S. McNeilly, 1998. Effects of level of food intake on ovarian follicle number, size and steroidogenic capacity in the ewe. Anim. Reprod. Sci. 52, 131-138.

Rhind S.M., I.D. Leslie, R.G. Gunn and J.M. Doney, 1986. Effects of high levels of body condition and food intake on plasma follicle stimulating hormone, luteinizing hormone, prolactin and progesterone profiles around mating in Greyface ewes. Anim. Prod. 43, 101-107.

Rhind S.M., G.Z. Wetherill and R.G. Gunn, 1990. Diurnal profiles of LH, prolactin and progesterone and their inter-relationships in ewes in high or moderate levels of body condition. Anim. Reprod. Sci. 24, 119-126.

Rondon Z., F. Forcada, L. Zarazaga, J.A. Abecia and J.M. Lozano, 1996. Oestrous activity, ovulation rate and plasma melatonin concentration in Rasa Aragonesa ewes maintained at two different and constant body condition score levels and implanted or reimplanted with melatonin. Anim. Reprod. Sci. 41 (3-4), 225-236.

Russel A.J.F., J.M. Doney and R.G. Gunn, 1969. Subjective assessment of body fat in live sheep. J. Agric. Sci. Camb. 72, 451-454.

SAS 2004. SAS, ver 9.1. Qualification Tools User's Guide. SAS Institute, Inc, Cary, NC, USA.

Schruder U.J. and R. Staufenbiel, 2006. Invited review: Methods to determine body fat reserves in the dairy cow with special regard to ultrasonographic measurement of backfat thickness. J. Dairy Sci. 89 (1), 1-14.

Silva S.R., M.J. Gomes, A. Dias-da-Silva, L.F. Gil and J.M. Azevedo, 2005. Estimation in vivo of the body and carcass chemical composition of growing lambs by real-time ultrasonography. J. Anim. Sci. 83(2), 350-357. 
Thomas V.M., M.J. McInerney and R.W. Kott, 1988. Influence of body condition and lasalocid during late gestation on blood metabolites, lamb birth weight and colostrum composition and production in Finn-cross ewes. J. Anim. Sci. 66, 783791.

Thompson M.I. and P.R. Cheeke, 2005. "Feeding and Nutrition of Small Ruminants": Sheep, Goats and Lamas, Applied Animal Nutrition, $3^{\text {rd }}$ Edition, by Peter R. Cheeke, Pearson Prentic Hall, New Jersy, USA.

Tolkamp B.J., G.C. Emmans and I. Kyriazakis, 2006. Body fatness affects feed intake of sheep at a given body weight. J. Anim. Sci. 84, 1778-1789.

Wallace J.M., J.S. Milne and R.P. Aitken, 2010. Effect of weight and adiposity at conception and wide variations in gestational dietary intake on pregnancy outcome and early postnatal performance in young adolescent sheep. Biol. of Reprod. 82 (2), 320-330.

West K.S., H.H. Meyer and R.G. Sasser, 1989. Ewe body condition and nutrition effects on embryonic loss. J. Anim. Sci. 67(Suppl. 1), 424 (Abstr.). 


\section{درجة الحالة الجسمانية للنعاج المصرية: هل تؤثر على الأداء التتاسلى و الإنتاجى؟ إبراهيم إبراهيم عبد المجيد}

قسمم الإنتاج الحيوانس، كلية الزراعة، جامعة القاهرة، مصر

تم فى الدراسة استخدام عدد برا نعجة ممثلة لأنواع الأغنام المصرية الرئيسية الثلاث

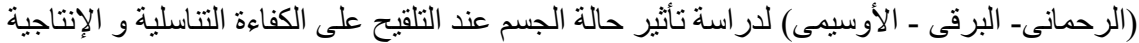

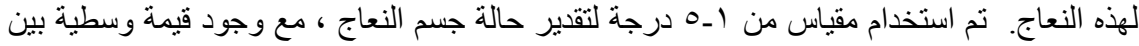

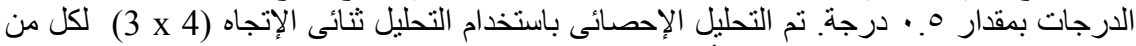

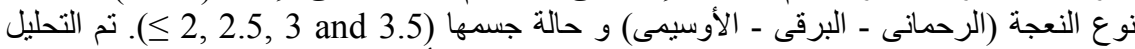

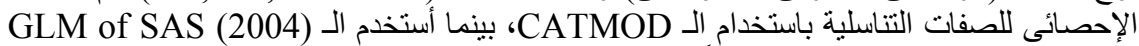

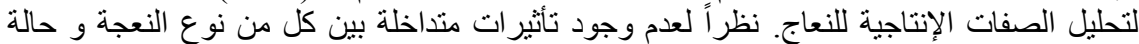

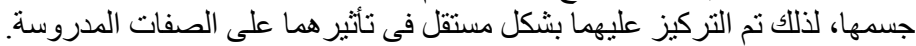

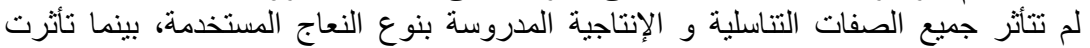

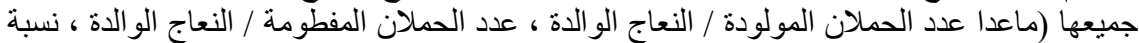

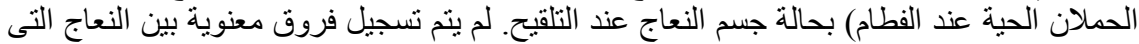

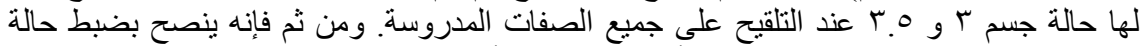
جسم النعاج للارجة ب عند التلقيح لتعظيم أربحية قطعان الأغنام الغنام. 